\title{
Lietuvos ir Rusijos santykiai: tarp neigiamų nuostatų ir pragmatiško bendradarbiavimo
}

\begin{abstract}
Lietuvai tapus Europos Sajungos ir NATO nare, keičiasi ir jos santykiai su Rusija. Bet tai iš esmès šių santykių nepablogino. Šalys ir toliau plètoja abiem pusèms naudingus ekonominius ir kultūrinius ryšius, regioninį bendradarbiavimą. Todèl Rusijos santykiai su Lietuva išlieka glaudesni nei su kitomis Baltijos šalimis. Vis dèlto šiuose santykiuose vis dar nėra galutinai atsisakoma išankstinių neigiamų nuostatų ir ne visada žiūrima abipusès naudos, o ilgalaikė perspektyva atrodo optimistiškai. Kadangi Rusijos santykiai su Jungtinėmis Valstijomis ir Europos Sajunga gerès, šalys stengsis mažiau konkuruoti, skatins bendradarbiavimą ir partnerystę, tai neišvengiamai teigimai veiks ir santykius su Baltijos šalimis.
\end{abstract}

\section{Ivadas}

Lietuvos ir Rusijos socialiniai, politiniai ir kultūriniai ryšiai turi gilias istorines šaknis. 1980-1990 metais, keičiantis geopolitiniam žemèlapiui ir užsienio politikai, prasidèjo naujas šalių bendravimo laikotarpis. Tai buvo itin svarbus žingsnis abiejų šaliu istorijoje.

Kas šiuo metu svarbiausia Lietuvos ir Rusijos santykiuose? İ ši klausimą sunku vienareikšmiškai atsakyti. Lietuva, sėkmingai įveikusi pasiruošimo etapa, tapo visateise Europos Sajungos ir NATO nare. Nepaisant to, Rusijos vaidmuo šiame regione yra labai svarbus - tiek ekonomikoje, tiek ir politikoje. Tačiau šis vaidmuo nėra visuomet palankiai vertinamas. Pasak Rusijos vadovu, jai Lietuva nèra labai svarbus prekybos partneris, tik Rusijos šiaurès vakarų regionas yra glaudžiau susijęs su Lietuva. Vis dèlto abi šalis sieja ne tik ekonominiai ryšiai.

Pirmiausia - istoriniai ryšiai. Ilgą laiką Lietuva ir Rusija įejo ị vieną valstybę - Sovietų Sajungą. Joje buvo įdiegtas bendras ūkis, energetikos (taip pat ir branduolinès), transporto ir tranzito sistemos buvo glaudžiai susijusios. Lietuva netgi buvo labiau susijusi su Rusija nei kitos dabartinės Nepriklausomu valstybių sandraugos (toliau - NVS) šalys.

\footnotetext{
* Dr. Leonid Karabeškin yra Sankt Peterburgo Baltijos klubo pirmininkas ir Talino Eurouniversiteto (Euroülikool) docentas. Adresas: P.O. Box 488, 191123 St Petersburg, Russia, tel. +372 6115229, el.paštas: baltclub@mail.ru.
} 
Taip pat reikètų paminèti politinio bendravimo svarbą. Yra žinoma, kad Rusijos santykiai su Lietuva (ir kitomis Baltijos šalimis) buvo lyg „barometras", rodantis pokyčius tiek šalies viduje, tiek ir užsienio politikoje, siekiant tarptautinės bendruomenès pripažinimo. Nors šis procesas ne visuomet buvo sklandus ir sėkmingas, jis, be abejo, yra labai svarbus abiem šalims.

Būtina paminèti, kad Lietuva neturi tarpvalstybinès sienos su „didžiąa“” Rusija - tik su Kaliningrado sritimi. Kiekvienai valstybei labai svarbu stabilumas kaimyninių šaliu viduje, o nedraugiški kaimynai tik sunkina šalies gyvenimą. Sprendžiant Kaliningrado klausimą, pabrėžiami tiek geros kaimynystės santykiai, tiek ir teritorinių kliūčiu problema. Kaliningradas yra Rusijos dalis, tačiau neturi sausumos sienos su ja. Spręsdami šį klausimą, Rusijos politikai pabrèžia tranzito į šią sritị svarbą. Pirmiausia nurodomas keleiviu, kroviniu ir karinis tranzitas, taip pat žaliavų ir energetinių ištekliu gabenimas per Lietuvos teritoriją. Pasak politiku, tai pagrindiniai Kaliningrado pragyvenimo ištekliai.

Lietuvai tapus Europos Sajungos ir NATO nare, keičiasi ir jos santykiai su Rusija. Būdama NATO nare, ji stengèsi formuoti Aljanso šalių požiūrị i Rusiją. Tačiau kaip nedidelè periferinè šalis, Lietuva ėmėsi ir kitokių uždavinių. Ji padeda organizacijai bendrauti su NVS šalimis. Vašingtonas palaiko šią iniciatyvą, nors šis regionas yra Rusijos įtakoje. Lietuvos žingsniai pakeitė „Šiaurès Europos iniciatyvos“ projekto tikslus. Dabar jis vadinasi „Partnerystès stiprinimas Šiaurès Europoje". Lietuvos veiksmai sustiprino Europos Sajungos „Europos plètra - nauji kaimynai“ iniciatyvą. Dabartinis plètros projekto pavadinimas yra „Europos kaimynystès politika“.

Nei auganti Europos Sajungos ir JAV įtaka NVS šalyse, nei nepalankus Maskvos požiūris į anksčiau minėtas iniciatyvas iš esmès nepablogino Lietuvos ir Rusijos santykių. Šių šalių aukščiausio lygio tarpvalstybinis bendravimas skatino priimti abiem pusėms naudingus ekonominius projektus. Rusijos santykiai su Lietuva yra glaudesni nei su kitomis Baltijos šalimis. Norètųsi pabrèžti, kad santykiuose tarp valstybiu vis labiau atsisakoma išankstinių neigiamu nuostatu ir žiūrima abipusès naudos. Ekonominis bendradarbiavimas, abieju šalių vidaus ir užsienio politika tik sustiprina šiuos žingsnius. Tačiau šis kelias ne visuomet yra lengvas.

\section{Ekonominiai Lietuvos ir Rusijos ryšiai}

Per pastaruosius dešimt metų Rusija yra pagrindinis Lietuvos prekybos partneris. Remiantis statistikos duomenimis, eksportas į Rusiją ir importas iš jos sudare 10,4 ir 27,8 procentus. 2006 metų sausio-liepos ménesiais eksportas sudarè 11,3 procentus, o importas 27,9 procentus 1 .

Rusija yra žaliavų tiekëja, Lietuva teikia transporto ir tranzito paslaugas. Rusija taip pat lieka pagrindinè dujų tiekejja Lietuvai (beje, 2006 metais dujų kai-

${ }^{1}$ LR Statistikos departamento duomenys, http://www.std.lt. 
nos buvo šiek tiek mažesnès nei Europai - 135 JAV dolerių už tūkstantį kubiniu metru $)^{2}$. "Gazprom“ valdo „Lietuvos dujas“ ir „Dujotekana“", taip pat nusipirko Kauno šiluminę elektrinę. Tarpvalstybinè sutartis suteikia Lietuvos chemijos gigantui "Achemai“ pirkti dujas lengvatinemis sąlygomis. Be to, Lietuva yra pirmoji užsienio šalis, kurioje "Gazprom“ gamina elektros energiją. Pasak šios i̇monès atstovu, verslo plètra ir investicijos dar labiau sustiprès po Ignalinos atominès elektrinès uždarymo. Tuo pat metu "Gazprom" tikisi pradèti tiekti dujas Kaliningrado šiluminei elektrinei ${ }^{3}$. Pradejjus šią veiklą, sumažètų duju pardavimas kitam Rusijos milžinui - RAOJES. Ši strategija dèstoma "Gazprom“ "Investicijų memorandume ${ }^{\prime 4}$.

Bendradarbiaudama su Rusija privatizuojant duju bendroves, Lietuva dar kartą įrodė pragmatišką požiūrị šiuo klausimu. Rusija buvo ir liks labai svarbi žaliavų tiekẻja. Geri kaimyniški santykiai užtikrina nenutrūkstamą žaliavų tiekimą Lietuvai. Tačiau "Mažeikių naftos“ privatizavimas įrodė, kad politiniai veiksniai gali nulemti ekonominius. Po nesékmingo sandorio su Jungtinių Valstiju bendrove "Williams", 2002 metais gamykla tapo Rusijos naftos kompanijos ",Jukos" nuosavybe. Sandoris su "Jukos“ garantavo stabilu naftos tiekimą Mažeikiams. Imonè pradejjo dirbti pelningai. Tačiau padètis pasikeitè bankrutavus Jukos bendrovei (yra žinoma, kad Rusijos valdžia daré įtaką šiam procesui). Koncernas pradejjo pardavinèti savo akcijas (taip pat ir "Mažeikių naftos"), nes prarado galimybę naudotis valstybiniu "Transneft" naftotiekiu.

"Jukos" kompanijos užsienio akciju (taip pat ir "Mažeikių naftos“) pardavimas buvo sudėtingas. Rusijos valdžia, rodės, tam neskyrẻ ypatingo dèmesio. Visas turtas turejo atitekti bendrovei „Rosneft", perèmusiai "Jukos“ isiskolinimus. Tačiau šis procesas nebuvo sklandus, nes daugelis ,Jukos“ turto priklausè dukterinei įmonei, registruotai Olandijoje. Nors Rusijos bendrovès "Lukoil“ ir „TNK-BP“ dalyvavo Mažeikiu naftos pardavimo sandoryje, jo nelaimèjo. Naftos perdirbimo įmoné buvo parduota Lenkijos bendrovei „PKN Orlen“, aplenkusiai didesnę kainą siūliusią Kazachstano „KazMunaiGaz“. Ivvykus sandoriui su „PKN Orlen“, “Družba” naftotiekyje įvyko avarija. Dèl šio įvykio sumažėjo naftos tiekimas Mažeikiams, o atšaka į Biržus buvo uždaryta. Rusijos valdžia aiškino, kad naftotieki reikia uždaryti ilgalaikiam remontui. Tačiau daugelis įžvelgé politinius šio sprendimo motyvus.

Dalyvaudamos privatizavime, Rusijos energetikos bendrovės varžėsi ir konkuravo tarpusavyje. Tai nutiko dèl Rusijoje galiojančio energetikos įmoniu valdymo modelio. Tiek šalies viduje, tiek ir užsienyje bendrovės valdomos pagal griežtą vertikalès principą. Nors Rusijai ir trūksta modernių naftos perdirbimo imoniu, jos kompanijos nesistengè permokèti už „Mažeikių naftą“. Kita vertus, „PKN Orlen“ ir „KazMunaiGaz“ bendrovėms įsitvirtinimas naujoje naftos perdirbimo ir tranzito rinkoje buvo valstybinès svarbos uždavinys.

\footnotetext{
2 „President Litvy nagovoril na \$30: Gazprom prodolzhaet povyshat' ceny“, Kommersant, May 5, 2006.

${ }^{3}$ Butrin D., Vodo V., „Litva proschaetsia s "Lietuvos dujos“, Kommersant, March 25, 2004.

${ }^{4}$ Žr.: http://www.akm.ru/rus/news/2006/october/17/ns1795851.htm.
} 
Rusu „,taupumą“ lėmė keletas veiksnių. Manyta, kad lenkų ir kazachu bendrovėms nepavyks užtikrinti stabilaus naftos tiekimo "Mažeikių Naftai". Lietuvos valdžios atstovai suvokè, kad vienintelis žaliavų tiekejjas yra Rusija. Alternatyvus naftos gabenimas per Būtingės terminalą nèra visiškai patikimas. Jeigu žaliavos būtų gabenamos tik per šį terminalą, tai taptų nepelninga naftos produktų kainoms smarkiai sumažèjus. Lietuva atsidurtų sunkioje padėtyje, nes Rusijos bendrovès negarantavo stabilaus naftos tiekimo įmonei, kuri jiems nepriklausè. Be to, ateityje vis mažiau rusiškos naftos tekès Vakarų kryptimi, nes didžioji dalis bus nukreipta ị Kiniją.

Konkurse perkant "Mažeikių naftą“ dalyvavo Kazachstano bendrovė „KazMunaiGaz“. Šiai bendrovei būtu pavykę susitarti dèl pastovaus naftos tiekimo į Lietuvą. Rusija ir Kazachstanas palaiko draugiškus tarpusavio ryšius, o ju prezidentai V. Putinas ir N. Nazarbajevas yra sutarę dèl keleto bendru projektų energetikos srityje. Netrukus planuojama dali vakarams skirtos naftos pradèti tiekti iš Kazachstano ${ }^{5}$. 2005 metų lapkričio mènesį didžiosios Rusijos bendrovès susitarè panaikinti naftos tiekimo apribojimus, jeigu „Mažeikiu nafta“ atitektu „,KazMunaiGaz“ bendrovei ${ }^{6}$. Todèl buvo manoma, kad Lietuvos Vyriausybè tikrai rems ši sandorị.

Lietuvos Vyriausybė nedalyvavo derybose dèl „Mažeikių naftos“ akciju pardavimo. Tačiau jos nuomonè buvo tvirta - Mažeikiai neturi atitekti Rusijos bendrovėms. Pasak buvusio užsienio reikalų ministro A.Valionio, „Mažeikių naftos" pardavimas yra ne tik prekybinis sandoris, bet ir ypatingai svarbus geopolitinis sprendimas ${ }^{7}$. Laimejjusi ši mūšĭ, Lietuva iškovotų nepriklausomybę nuo Rusijos naftos tiekëju. Ekspertų nuomone, reikėtų sukurti bendrą Vidurio Europos naftos perdirbimo koncerną. Tai pavyktų igyvendinti sujungus Lietuvos, Lenkijos, Austrijos ir Vengrijos bendroves.

Vyriausybès požiūrị sąlygojo šalyje vyravusios nuotaikos dèl naftos sektoriaus perèjimo Rusijos žinion. Ne visiems patiko atvirai reiškiamas Rusijos noras įsitvirtinti Europos rinkoje perimant energijos sektoriaus lyderio pozicijas. Kai kurios politinės jëgos netgi baiminosi, kad Lietuva praras savarankiškumą, ji vèl bus fiktyvių Rusijos bendrovių įtakoje, o už jų stovėtų Rusijos valdžia; "Mažeikių nafta" būtu puiki priedanga neskaidrioms finansinems operacijoms.

Tačiau pernelyg trumparegiška būtų manyti, kad valstybės parama Rusijos naftos sektoriaus plètrai turi tik politinius tikslus. Nèra teisinga manyti, kad, kontroliuodama energijos ištekliu gamybą, Rusijos valdžia kontroliuos Lietuvos politini gyvenimą. Kiekviena šalis turi verslo interesu, todèl daugelis kompaniju stengiasi įsitvirtinti tarptautinëje rinkoje. Lietuva yra labai naudingas partneris:

\footnotetext{
${ }^{5}$ Zaslavsky I., „Delo truba. Baku - Tbilisi - Ceyhan i kazakhstanskii’ vybor na Kaspii“, Moscow: Europe, 2005. p. 71.

${ }^{6}$ „Veselye sosedi. Khoroshie druz'ia“, Expert, no. 44. November 21, 2005. http://www.expert.ru/printissues/ expert/2005/44/44ex-pov11.

${ }^{7}$ BNS, „A.Valionis: „Mažeikių naftos“" pardavimas Lenkijai - geopolitinio mūšio dalis“, 2006 rugsèjo 5 d.

${ }^{8}$ Janeliūnas T., Molis A. „The NGEP Ends Lithuania’s Hopes of Becoming Transit Country“, Baltic Mosaic, 2005, no. 1. p. 30-31.
} 
investavusi i „,Mažeikių naftą", Rusijos Vyriausybė užtikrintų stabilų energijos ištekliu tiekimą Vakarams ir sustiprintų strategines investicijas užsienyje. Be to, po keleto nesékmingų sprendimu, kaip antai "Severstal“ ir "Anchelor" susijungimo, šalies verslininkai atgautu pasitikejjimą savo jẻgomis.

Dar viena bendra veikla, jungianti Kaliningrado ir Klaipèdos uostus, sulauke Lietuvos Valstybès saugumo departamento (VSD) kritikos. Buvo įtariama, kad 2000 metais pradètam projektui įtaką daro Rusijos specialiosios tarnybos. 2003 metais Lietuvos VSD apkaltino Rusiją stengiantis didžiają savo kroviniu dalị nukreipti iš Klaipedos ị Kaliningrado uostą. Tiesa, kroviniu srautas 2000-2003 metais sumažèjo 5 kartus iki 5,3\%9. Tačiau tuo metu uostus jungiantis $2 \mathrm{~K}$ projektas dar negaliojo, buvo tik aptariamos jo detalès. Klaipėdos ir Kaliningrado bendradarbiavimui trukde tiek tarpvalstybiniai, tiek ir vidaus nesutarimai. Reikètų paminèti dvi Lietuvos bendroves - „Lietuvos geležinkelius“ ir "Klaipėdos uostą“" traukiniais gabenami kroviniai į Kaliningrado uostą aplenkè Klaipėdą.

2005 metu gegužès mėnesi Trakuose pasirašius dviejų uostų bendradarbiavimo susitarimą, Rusijos krovinių skaičius Klaipėdos uoste gerokai išaugo. 2005 metais jis buvo $16 \%{ }^{10}$. Sunkoka pasakyti, ar $2 \mathrm{~K}$ projektas tiesiogiai sąlygojo krovinių srauto pasikeitimus, tačiau jis sustiprinimo Lietuvos ir Rusijos ryžtą bendradarbiauti transporto ir tranzito srityje. Prezidentas Putinas, 2005 metais lankydamasis Kaliningrado srityje, kalbëjo: „Vienintelis teisingas kelias yra dirbti kartu. Nors vykdant Klaipedos ir Kaliningrado projektą vis dar iškyla sunkumu, mūsų šalys bendradarbiaudamos turètų juos išspręsti“ “11. Rusijos geležinkelių kompanijos RŽD vadovas Vladimiras Jakuninas kalbėdamas apie ateities planus Lietuvą minëjo kaip vieną iš perspektyviausių partnerių. Krovinių tranzitas geležinkeliais per Lietuvos teritoriją 2005-2010 metais turètu išaugti iki $40 \%{ }^{12}$.

K2 projekto Lietuvoje sukeltas skandalas įrodo, kad politiniai ar net geopolitiniai veiksniai lemia ekonominius sprendimus. „Mažeikių naftos" privatizavimas gerokai pablogino Lietuvos ir Rusijos savitarpio pasitikëjimą, sukèlè įtarimu, kad politika lemia ūkio raidą. Lietuva įtaria Rusiją sąmoningai nutraukus naftos tiekimą Mažeikiams ir nurodo, kad geležinkelių sistemai irgi reikia renovacijos. Pradejjus taisyti geležinkelius, kiltų rimtų sunkumų kroviniu tranzitui ị Kaliningrado sritį. Atsakydama ị toki pareiškimą, Rusija atidarẻ naują krovininę kelto liniją „Ust-Luga - Baltijsk“.

Nepaisant sunkumų, abieju šaliu ekonominis bendradarbiavimas plečiasi. Puikus pavyzdys yra eksporto kvotu padidinimas Rusijos metalurgijos pramonès paslaugu teikimo centrams Lietuvoje ir Latvijoje. Lengvatos suteiktos Lietuvai jau tapus Europos Sajungos nare ${ }^{13}$. Atsiradus galimybėms

\footnotetext{
${ }^{9}$ Manomaitytė M., „Podpisanie proekta 2K garantiruet okonchanie tarifnoj voiny?“, Jura, no. 3. 2005.

${ }^{10}$ Skripov V. „Tretii’ vystrel“, Expert Severo-Zapad, no. 32. September 4, 2006.

${ }^{11}$ Interfax - Zapad, September 11, 2006, http://www.interfax.by/?id=33\&id_sp=26683\&d=11\&m=09\&y $=2006 \&$ lang $=\mathrm{ru}$

${ }^{12}$ REGNUM, 2006 m. balandžio12 d., Regnum, April 12, 2006, http://www.regnum.ru/news/622734.html.

${ }^{13}$ Joint Statement on EU Enlargement and EU-Russia Relations. Luxemburg, April 27, 2004, http://ec.europa eu/comm/external_relations/russia/russia_docs/js_elarg_270404.htm.
} 
Rusijos plieno gamykla „Mechel“ įsigijo Kauno metalo apdirbimo įmonę „Nemunas“. Dar viena kaimynų bendrovė „Konversbank“ nusipirko vieno didžiausiu mažmeninio banko „,Snoras“ akcijas. Deja, tai labai nedidelis sėkmingų sandoriu skaičius, nors Rusijoje ir pabrěžiama investavimo Europoje svarba, o Baltijos šalys turètu padèti Rusijos kapitalui pasiekti kitas Europos šalis ${ }^{14}$.

Nors ir baimintasi, kad, Lietuvai tapus Europos Sajungos nare, verslo reikalai pablogès, padètis beveik nepasikeitè. Remiantis 2005 duomenimis, Lietuvos prekybos apyvarta Rusijoje buvo 1,4 \% (2004 metų gegužès-gruodžio laikotarpiu $-1,3 \%)^{15}$. Nedidelis augimas pastebètas dèl to, kad didèjo visa užsienio prekybos apimtis.

\section{Užsienio politika}

Rusijos politinių prioritetų skalejje Lietuva neužima aukščiausios vietos, tačiau jos vaidmuo yra neabejotinai svarbus. Reikètų paminèti Rusijos strategiją Baltijos šalyse, Kaliningrado problemos sprendimą, santykius su Jungtinemis Valstijomis ir Europos Sajunga. Sprendžiant nelengvus politikos klausimus, Lietuva nelieka nuošalëje.

\subsection{Rusijos politika Baltijos šalyse}

Maskvos Baltijos politika nuolat sąlygojo prieštaringą Rusijos ir Lietuvos santykių kontekstą. Viena vertus, pati sąvoka "Baltijos šalys" Rusijoje igavo negatyvią prasmę, nes asocijavosi su rusų etninès mažumos diskriminacija, NATO plètra, pastangomis , perrašyti" istoriją ir nemalonių istorijos laikotarpių šlovinimu, o taip pat ir su paprasčiausia nostalgija prarastai SSRS. Atitinkamai terminas Pribaltika - sovietinis triju Baltijos respubliku pavadinimas - šiandien turi revanšistinị atspalvị. Antra vertus, Rusijos Baltijos politikoje Lietuva visada galëjo naudotis "didžiausio palankumo" palyginus su kitomis Baltijos šalimis statusu.

Tarpvalstybiniai Lietuvos ir Rusijos santykiai prasidejjo 1989-1991 metais. Tuometinė Rusijos Federacijos valdžia, priešindama save Sovietų Sajungos valdžiai, su Lietuva, Latvija ir Estija slapta sudare taktinę sajungą. Subyrëjus Sovietu Sajungai, keitėsi ir Rusijos užsienio politikos kursas. Būdama didelė valstybė, ji stengèsi išlaikyti buvusią galybę. Kaip ir prieš kelis dešimtmečius, globalūs interesai buvo svarbesni nei siauros regioninės problemos.

1993 metais Maskva sutiko išvesti iš Lietuvos savo kariuomenę anksčiau nei iš Latvijos ir Estijos. Tačiau ne visuomet jos veiksmai buvo geranoriški: 1992_ 1993 metais prasidèjo Baltijos šalių energetinè blokada. Šie Maskvos žingsniai ịrodè, kad ekonominis spaudimas gali tarnauti politiniams tikslams.

${ }^{14}$ „Rossiia i Pribaltika II. Report“, Moscow: Council on Foreign and Security Policy (SVOP), 1999, http:// www.svop.ru/live/materials.asp?m id $=6883 \& \mathrm{r}$ id $=6915$.

${ }^{15}$ Based on data of the Federal Customs Service of the Russian Federation, http://www.customs.ru/ru/stats/ arkhiv-stats-new/popup.php?id286=125. 
Nors, išvedus kariuomenę, Baltijos šalys atgavo visišką nepriklausomybę, Rusijos spaudimas buvo jaučiamas ir toliau. 1996 metais parengtas „Ilgalaikio strateginio bendradarbiavimo su Baltijos šalimis" dokumentas. Jame aptariami svarbiausi klausimai: rusakalbių tautinių mažumų teisès Lietuvoje, Latvijoje ir Estijoje, triju valstybių planai tapti NATO narėmis. Tuo metu Rusijos tikslas buvo sustabdyti Baltijos valstybiu stojimą iz NATO. Siekdama savo tikslų, Rusija kiekvienai šaliai parengè skirtingą „Strateginį veiksmų planą“. Vienas iš svarbiausių tikslų buvo ekonominių ryšių išsaugojimas ir plètra. Kalbėdama apie gerus kaimynystės santykius, Maskva iškẻlè keletą reikalavimų. Pirmiausia - Baltijos šalyse privalejo būti gerbiamos mažumų teisės, taip pat pasiūlyta atsisakyti narystės NATO. Savo ruožtu Rusija pažadèjo pasirašyti visas tarpvalstybines sienos sutartis. Lietuvai sekèsi lengviausiai. Rusakalbiai gyventojai gavo Lietuvos pilietybę, taip pat prasidëjo derybos dèl tranzito į/iš Kaliningrado srities. Latvija ir Estija buvo dažnokai lyginamos su Lietuva, derybos su Maskva joms buvo daug sunkesnès. Šiose šalyse buvo jaučiamas daug didesnis Rusijos spaudimas.

1996-1997-ieji metai buvo sèkmingi Lietuvos derybininkams. Baigiantis 1996 metams, buvo susitarta dèl Rusijos karinio tranzito per Lietuvą. Kitais metais pasirašyta sutartis, nustatanti Baltijos jūros šelfo ribas. Panašūs susitarimai buvo parengti su Latvija ir Estija, tačiau patvirtinti tik beveik po dešimties metu - 2006-aisiais. Pasirašant tarpvalstybinę sutartị su Lietuva neišvengta ir sunkumų. Tuometinis Rusijos Prezidentas Borisas Jelcinas sulaukė aršios Valstybės Dūmos kritikos, netgi grasinta, kad sutartis iš viso nebus ratifikuota ${ }^{16}$. Buvo teigiama, kad Lietuva nepakankamai efektyviai sprendžia Rusijos tranzito į Kaliningrado sriti problemas, išreikštos neigiamos nuostatos dèl stojimo i NATO. Netgi buvo bandoma pasinaudoti rusakalbiu teisiu ",korta“"17. Kai kurie Maskvos politikai išreiške abejonių dèl Klaipėdos krašto prijungimo prie Lietuvos po Antrojo pasaulinio karo. Sienos sutartis su Lietuva ratifikuota tik 2003 metais ir tik po to, kai buvo pasirašyti susitarimai dèl tranzito į Kaliningrado sriti. Skirtingai nuo Estijos Lietuva (ir Latvija) susitare didžiausio palankumo tarpusavio prekyboje.

Ne tik grasinimu ėmėsi Maskva, norėdama patraukti Baltijos šalis į savo pusę. 1997 metais Rusija pasiūlè daugiašalès gynybos garantijas, jeigu šios valstybės atsisakytu stoti į NATO. Tokios mintys sulaukè kai kuriu politiku pritarimo. Kalbejdamas spaudos konferencijoje Maskvoje, Lietuvos Respublikos Prezidentas Algirdas Brazauskas pabrèžè, kad be reikalo taip griežtai atmetamos Rusijos Prezidento pasiūlytos garantijos. Nepaisant to, Baltijos valstybiu vadovai vieningai atmetè Maskvos garantijas ir nusprendè, kad vienintelis kelias yra integracija į euroatlantines struktūras. Tačiau Rusijos valdžia - Prezidentas B. Jelcinas, Ministras Pirmininkas V. Černomyrdinas, užsienio reikalų ministras

\footnotetext{
${ }^{16}$ Vitkus G., „Lithuanian-Russian Relations in 1990-1995. A Study of Lithuanian Foreign Policy“, Untersuchungen des FKKS an der Universität Mannheim, 12/1996, p. 17; http://www.uni-mannheim.de/fkks/fkks12. pdf.

${ }^{17} \breve{Z r}$. Address of the State Duma to President of the Russian Federation on planned signing of the Border Treaty between the Russian Federation and the Republic of Lithuania], adopted September 26, 1997, http:// www.akdi.ru/gd/post/19352GD.htm.
} 
J. Primakovas - nenuleido rankų. Jie netgi pažadejo, kad 40\% sumažins savo karines pajėgas Šiaurės Vakarų regione, taip pat ir Kaliningrado srityje. Deja, Maskvos iniciatyva nesudomino Baltijos užsienio politikos specialistų. Tikèta, kad Rusijos žingsnius lèmé sunki armijos padètis.

1998 metu Rusijos finansinė krizè ir po jos prasidèjusi vidinė politinė krizė lëmè, kad didesnis dėmesys teko ekonomikos klausimams, o Baltijos politikos reikalai atsidūrẻ Rusijos užsienio politikos periferijoje. Tačiau Rusija gana padrikai reagavo į politiškai motyvuotą „Mažeikių Naftos“ privatizavimą bei savo kadenciją baigiančio 2000 metais Seimo priimtą įstatymą "dèl SSRS okupacijos žalos atlyginimo". Šiuo laikotarpiu Rusija aiškiai nepajègè koordinuoti savo užsienio politikos ir atstovauti savo įmoniu ekonomiu interesu užsienyje. Dèl to kai kurios bendrovès netgi pasidavè pagundai imtis veiklos, kuri neretai neatitiko Rusijos nacionaliniu interesu.

Makroekonomine ir politine situacija šalyje stabilizavosi į valdžią atëjus Vladimirui Putinui. Jo vadovavimo laikotarpis, daugelio specialistų nuomone, yra „pragmatizmo era“"18. Imta labiau domètis kaimyniniu valstybiu gyvenimu. Rusija suprato, kad NATO ir Europos Sajungos plètra yra neišvengiama, taigi stengiamasi tiesiog sušvelninti jos padarinius. Maskva suvokia, kad svarbu yra palaikyti ekonominius ryšius su Baltijos šalimis, todèl ekonominė nauda yra lemiamas veiksnys priimant politinius sprendimus. Baltijos šalys daugiau nebejaučia Maskvos spaudimo ir grasinimų nepasirašyti sutarčių. Šiuo laikotarpiu su Latvija ir Estija suderinamos dvišalès sienų sutartys. Lietuva ratifikuoja dvišalę sutarti su Rusija.

Putino valdymo laikotarpiu keitėsi Maskvos tonas ginant rusakalbiu gyventoju teises Baltijos šalyse. Duodamas interviu Suomijos žurnalistams, Rusijos Prezidentas pabrèžè, kad spręsdamos šị klausimą abi šalys neturètu pabloginti tarpvalstybinių santykiu, pablogëjusi padètis neigiamai atsilieptu patiems rusams, gyvenantiems Baltijos šalyse ${ }^{19}$. Santykiai pagerèjo ir dèl permainu kaimyninèse šalyse. Estijos Prezidentu išrinktas buvęs nuosaikus Sovietinės Estijos vadovas Arnoldas Ruutelis. Beveik to pačiu metu Lietuvoje sudaryta kairiujų centro koalicija, vadovaujama Algirdo Brazausko. Stiprëjant antirusiškoms nuotaikoms NATO ir Europos Sajungos institucijose Baltijos šalims teko ypatingas vaidmuo: jos tarytum jungė Vakarų Europą, Ameriką ir Rusiją.

2000 metų pradžioje sustiprëjo Lietuvos ir Rusijos politinis dialogas. 2001ujų metų kovo mènesį Prezidentas Valdas Adamkus su oficialiu vizitu lankèsi Maskvoje ir Kaliningrade. Nepaisant Lietuvos diplomatu pastangu, vizito metu tarpvalstybinė sienos sutartis nebuvo ratifikuota. Tačiau viena svarbi pergalė buvo pasiekta - pasirašyta bendra Lietuvos ir Rusijos Deklaracija ${ }^{20}$. Šiame dokumente Rusija pripažino Lietuvos teisę tapti NATO nare motyvuodama tuo, kad kiekviena šalis turi teisę pasirinkti jai geriausią gynybos sistemą, tačiau

18 Žr. pvz. „Rossiia i Baltia: 2010. Report“. Moscow: Foundation for Prospective Studies and Initiatives, April 2003, http://www.psifoundation.ru/publications/2003/05/baltika1.htm.

${ }^{19}$ Interview of V.Putin to Helsingen Sanomat, September 1, 2001.

${ }^{20}$ Žr.: http://www.kremlin.ru/text/psmes/2001/03/32255.shtml. 
neturètų sukelti grèsmės kaimynams. Lietuva vienintelè iš Baltijos šalių pasirašè su Rusija politinę deklaraciją. Su kitomis šalimis santykiai nebuvo tokie sėmingi: tų pačių metų pavasarị Ryga ir Talinas atmetè šį politinės valios dokumentą.

Abiejų valstybiu ryšiai sustiprejo, kai 2003 metais Lietuvos Prezidentu išrinktas Rolandas Paksas. Rusija džiugiai prièmė žinią apie žmogaus, gyvenusio ir baigusio mokslus Sankt Peterburge, išrinkimą valstybės vadovu ${ }^{21}$. Pasak Kremliaus atstovu, Putinas ir Paksas keletą kartų tiesiogiai bendravo telefonu. Pats Rusijos Prezidentas gyrè savo kolegą dèl innašo gerinant dvišalius santykius. Putinas pabrèžè, kad Pakso dèka dvišalis bendradarbiavimas igavo naują kokybę ${ }^{22}$. Savo ruožtu Paksas susitikime su Lietuvos ambasadoriais užsienio šalyse kalbëjo apie nuosaikesnę užsienio politiką. Jo žodžiais tariant, Lietuva daug išmoko bendraudama su Rusijos vadovais ir spręsdama Kaliningrado klausimą. Taigi ryšius reikètu plètoti, bendradarbiauti ir su kitais Rusijos regionais, o ypač su šiaurès vakarų ${ }^{23}$. Šio regiono valdžia džiugiai sutiko kaimynu iniciatyvą. Žinoma, Maskva irgi pritarè lietuviu pasiūlymui. Deja, Lietuvoje prasidejjusi politinè krize sustabdė projekto ígyvendinimą.

Pastaraisiais metais sumažèjo naftos tranzitas per Baltijos valstybiu uostus. Taip atsitiko todèl, kad Rusija smarkiai apribojo tranzitinių kroviniu skaičiu. Siekiant visiškos autonomijos, pradèta tiesti Baltijos vamzdynų sistema, sieksianti Leningrado srityje esantį Primorsko uostą. Naftos tiekimas yra vienas pagrindinių svertų, leidžiančių kontroliuoti šalių gyvenimą. Todèl Rusija ir stengiasi kontroliuoti naftos tranzitą per Baltijos valstybes. 2002 metais buvo priimtas sprendimas nutraukti tiekimą i Latvijos Ventspilio uostą. 2003-aisiais, igyvendinus šį nutarimą, nafta pradèjo tekèti ị Lietuvos Būtingès terminalą. Tačiau Rusijos vykdoma politika nesustabde trijų valstybių stojimo į NATO ir Europos Sajungą.

Rusijos politikai Baltijos valstybių atžvilgiu visuomet trūko nuoseklumo, todèl nepavyko išvengti NATO plètros ir pagerinti rusakalbiu gyventoju situacijos Latvijoje bei Estijoje. Antra vertus, Rusija suprato, kad ir kokie būtu politiniai nesutarimai, ekonominis bendradarbiavimas gali pagerinti abieju valstybių santykius. Jau keletą metų Rusijos ekonomika augo, didëjo jos įtaka pasaulyje. Su kitomis šalimis ji bendrauja ne tokiu įsakmiu tonu. Dabar Rusija nebijo pasirodyti silpna ir padaryti savo kaimynams tam tikru nuolaidu. O Baltijos šalys patiria mažesnị spaudimą, mažiau įtakojamas jų vidaus gyvenimas. Rusija pati vis labiau atsigręžia ị vakarus, stiprèja bendradarbiavimas su Vakaru Europos valstybėmis. Kaliningrado sritis tampa labai svarbus ekonomikos vystymo regionas.

\footnotetext{
${ }^{21}$ Words of V.Putin on Russia-EU Summit, St.-Petersburg, May 31, 2003, http://www.kremlin.ru/text/appears/2003/05/47580.shtml.

${ }^{22}$ Press-release of Press-service of President of Russia. 16 February, 2004, http://www.kremlin.ru/text/ psmes/2004/02/60665.shtml.

${ }^{23}$ Speech by H. E. Mr. Rolandas Paksas, President of the Republic of Lithuania, during the meeting with the Lithuanian Diplomatic Corps, February 27, 2004, http://paksas.president.lt/en/one.phtml?id=3602.
} 


\subsection{Kaliningradas}

Kaliningrado srities klausimas visuomet buvo svarbus tiek Rusijai, tiek ir Lietuvai. Rusijai visuomet rūpèjo politinis, ekonominis ir kultūrinis vientisumas. Nors Kaliningrado sritis yra atskirta nuo pagrindinės teritorijos, ji yra valstybės dalis, Rusija palaiko glaudžius ryšius su šia sritimi. Lietuvai irgi svarbūs ryšiai su Kaliningradu. Pasak Švedijos apžvalgininko Ingmaro Oldbergo, plètojant ekonomiką ši sritis galètų būti tiltu į Rusijos rinką ${ }^{24}$. Išlaikydama gerus santykius su Rusija, Lietuva padejo Europos Sajungai plètoti ryšius su šia sritimi. Kalbant apie Lietuvos ir Rusijos diplomatinius santykius, Kaliningrado srities klausimas visuomet buvo stabilizuojantis veiksnys. Dvišalès derybos nenutrūko net ir sunkiausiais 1999-2000 metais. 2000 metu vasario mènesi Nidoje abi šalys susitiko aptarti bendru projektu igyvendinimo. Susitikime pasiūlytas bendras Šiaurinio regiono veiksmu planas.

2004 metu gegužès mėnesi Lietuva tapo Europos Sajungos nare ir galės prisijungti prie Šengeno sutarties. Būdama Šengeno nare ji nebegalès laikytis visų ankstesnių susitarimų. Itin sudètinga tapo Kaliningrado tranzito problema. Šios srities gyventojai nebegalëjo kaip anksčiau keliauti per Lietuvos teritoriją, jiems reikèjo nauju vizų. Rusija pasiūlè suteikti lengvatines sąlygas Kaliningrado gyventojams. Pasak Maskvos, tai buvo viena išankstinių sąlygu pasirašant dvišalę sienų sutarti. Deja, Lietuva negalëjo priimti siūlymo, nes ją varžè Šengeno erdvès įsipareigojimai. Lietuvos atstovai bandè tartis su Briuseliu, bet pritarimo nesulaukè.

Kai kurie apžvalgininkai mano, kad Lietuva sąmoningai pasiūlè Briuseliui nepriimtinas sąlygas tam, kad išvengtu atsakomybės neduodama Kaliningradui tranzito ir vizų lengvatų. Rusijos užsienio reikalų ministerijos pirmasis sekretorius E. Gusarovas, kalbėdamas apie dvilypę politiką, pabrèžè, kad Lietuvos laikysena yra apgaulinga, ji vengia atvirai reikšti savo nuomonę, prisidengdama Europos nuostatomis ${ }^{25}$. Iš tiesų Kaliningradą sieja glaudūs ekonominiai ir kultūriniai ryšiai su Lietuva. Todèl klaidinga manyti, kad buvo sudaromas nepalankus vizų ir tranzito režimas. Lietuva netgi pasiūlè įvesti magnetines korteles, kurios Kaliningrado gyventojams palengvintu sienos kirtimą.

Derybose dèl vizų lengvatų Rusija pati ėmėsi iniciatyvos. Aukščiausiems pareigūnams pavyko susitarti su keliomis Europos šalimis, kad šios palaikytu ju iniciatyvą Briuselyje. Ilgai lauktas kompromisas buvo pasiektas 2002 metu lapkričio mėnesi aukščiausio lygio Europos ir Rusijos pareigūnų susitikime Briuselyje. Jis numatė kelionės dokumentų (geležinkelio transporto) palengvintą dokumentų įvedimą Kaliningrado gyventojams, keliaujantiems per Lietuvos teritoriją. Europai iš esmès pritarus, reikejjo susitarti su Lietuva. Lietuvos ir Rusijos derybos truko daugiau nei pusę metu - iki 2003 metu liepos. Tačiau dvišaliuose pokalbiuose dar kartą išryškëjo tarpusavio nepasitikẻjimas. Lietuva

\footnotetext{
${ }^{24}$ Oldber I., „Kaliningrad: Russian exclave, European enclave“, Stockholm: Swedish Defense Research Agency, June 2001, p. 43.

${ }^{25}$ Minutes of the State Duma session, June 19, 2002, http://www.akdi.ru.
} 
reikalavo pirmiausia ratifikuoti dvišalę sienų sutarti, tik tada žadejo suteikti Kaliningradui lengvatas. Maskva nesutiko, motyvuodama tuo, kad Lietuva nesilaiko dvišalio Rusijos ir Europos Sajungos susitarimo ${ }^{26}$. Tuo pat metu įvyko nesusipratimų Baltarusijos ir Rusijos (Kaliningrado srities) pasienyje, Lietuvos sienos apsaugos pareigūnams tikrinant keleivių dokumentus. Rusija šį žingsnį pavadino nepriimtinu, nes žmonės reikiamų dokumentų dar neturëjo.

Galu gale Rusijai ratifikavus sienos ir jūrinio šelfo sutarti, Lietuva patvirtino palengvintą vizų režimą (geležinkelio transportu) Kaliningrado srities gyventojams. Be šios sutarties, dar buvo pasirašytas susitarimas dẻl nelegaliu migrantu grąžinimo ị šalị. Lietuva - pirmoji užsienio šalis, su kuria Rusija pasirašè migracijos dokumentą. Ilgai trukęs vizų režimo derinimo procesas baigèsi. Dabartiniu metu tranzito problema yra išspręsta, abi šalys neturi viena kitai jokiu priekaištu. Keleiviams, tranzitu vykstantiems per Lietuvos teritorija, išduodamas laikinas kelionès pažymëjimas, jis yra prilyginamas šalies vizai ${ }^{27}$. Lietuvos Respublika įvedė papildomą asmens sveikatos draudimą keliaujantiems per jos teritoriją. Taip pat geležinkeliais draudžiama vežti tam tikrus stiprius vaistus. Dẻl šiu kelionès apribojimų sumažėjo žmoniu, vykstančių geležinkeliais, skaičius $^{28}$. Rusija buvo priversta atsisakyti sutarties tokiomis sąlygomis ir visiškai atidare „oro koridorių“ i Kaliningrado sriti. Analizuodama susidariusią padèti Užsienio reikalų ir saugumo taryba pastebëjo, kad dèl šio Rusijos žingsnio abieju šaliu santykiuose bus jaučiama įtampa ${ }^{29}$, nors tiek Lietuva, tiek ir Rusija vengé aštresniu pasisakymų. Visi sutinka, kad kiekviena suvereni šalis turi teisę žinoti, kas kerta jos teritoriją. Kita vertus, Rusijai pasiūlytas susitarimas nebuvo visiškai priimtinas. Reikia pastebėti, kad menamos tranzito per Lietuvos teritoriją grésmės nepasitvirtino, nebuvo né vieno nelegalaus migranto, pabejgusio iš traukinio, kurį reikètu deportuoti pagal readmisijos sutartị.

Ne tik keleiviu, bet ir karinio tranzito klausimas nebuvo galutinai išspęstas. Nepaisant pažadu, duotų Rusijai iki Europos Sajungos plètros, pastaraisiais metais tranzitas per Lietuvos teritoriją tapo brangesnis ir sudètingesnis. Išaugę tranzitinių krovinių kaštai padeda paslëpti kitus trūkumus - sumažèjusius pervežimus ị Kaliningradą ir kitus Rusijos regionus ${ }^{30}$. Karinius pervežimus apsunkina ir tai, kad nėra juridiškai reglamentuotos dvišalės sutarties. 2001 metu kovo 30 dieną „Bendrame Lietuvos ir Rusijos pareiškime“ Maskvoje minèta tokia galimybė. Dèl tokios padèties Lietuvos Vyriausybè vienašališkai tvarko

\footnotetext{
${ }^{26}$ Stenography of answers of Minister of Foreign Affairs of the Russian Federation I. Ivanov after the address in the Council of Federaion, Federal Assembly, March 26, 2003, http://www.mid.ru/brp_4.nsf/ sps/8BBCEA21DC27333243256CF50063BE92.

${ }^{27}$ The consular service of Lithuania informs, that FTD are made equivalent to visas, which does not allow entrance to other country, http://amb.urm.lt/kaliningradas/ambtopmenuitems.php?TopMenuID=1200\&Site $\mathrm{ID}=86 \&$ LangID $=3$.

${ }^{28}$ This trend tends to overcome only in 2006. Žr. Nilov A., „Na Kaliningradskoi' zheleznoi’ doroge vyros objem grozuperevozok i passazhiropotok", http://amb.urm.lt/kaliningradas/ambtopmenuitems.php?TopM enuID $=1200 \&$ SiteID $=86 \&$ LangID $=3$.

${ }^{29}$ „Otnosheniia Rossii i Evropei'skogo soiuza: Sovremennaia situaciia i perspektivy. Situation Analysis“. Under supervision of S. Karaganov, http://www.globalaffairs.ru/docs/report.doc.

${ }^{30}$ „Kak sdelat’ bolee effektivnoi’ sistemu sotrudnichestva Rossii i ES“, Moscow: Probel -2000, 2005. p $39-41$.
} 
visus karinius pervežimus per savo teritoriją. Rusijos siūlymas atidaryti greitojo (be sustojimo) traukinio liniją taip pat sulaukè neigiamų vertinimų. Baiminamasi, kad 2008 metais, Lietuvai tapus Šengeno šalimi ir panaikinus vidines Europos Bendrijos sienas, bus neịmanoma kontroliuoti krovinių srauto iš Kaliningrado.

Pasak Vilniaus ir Briuselio atstovu, Rusija per daug sureikšmina ši klausimą. Ji turètų daugiau domėtis ekonominiais ryšiais su Europos Sajunga. Tačiau tiek Rusija, tiek Lietuva, tiek ir Europa skirtingai ịsivaizduoja Kaliningrado srities ateitįi ${ }^{31}$ Nors ir oficialiai pabrèžiamas teritorinis vientisumas, pastaruju metu įvykiai rodo, kad norima Kaliningradą nutolinti nuo Rusijos. Pirmiausia yra ribojamas tranzitas, regionas netenka dalies paramos, kai tuo tarpu kitoms Lietuvos kaimynėms suteikiamos daug palankesnès sąlygos. Žinoma, Rusija privalëjo imtis atsakomujų veiksmų. Pirmas žingsnis, mažinantis tranzito skaičiu per Lietuvą, būtų žengtas atidarius geležinkelio perkèlą "Ust-Luga - Baltijskas“. Sio projekto autorius yra Rusijos Prezidentas Putinas. Antroji galimybè - kurti Kaliningrade laisvą ekonominę zoną, skatinti investicijas, tam tikroms įmonèms leisti naudotis privilegijomis. Lietuvai šiame regione atstovauja daugiausia tik smulkaus ir vidutinio verslo įmonès.

Derybose dèl Kaliningrado pasiekta nemažai laimejjimu, tačiau iškilo ir sunkumų. Spręsdamos šį klausimą, 1999-2000 metais abi šalys sẻdo prie derybu stalo, suvokdamos, kad tokiu keliu galima pasiekti laimejimų. Deja, ne viskas vyko sklandžiai. Tiek Lietuva, tiek ir Rusija siekia sau palankių sprendimų. Sunkumų kyla ir dèl to, kad trūksta abipusio pasitikejjimo ir supratimo. Visa tai stabdo bendradarbiavimą ir didina konkurenciją.

\subsection{Rusijos santykiai su Vakarų valstybėmis, jụ ịtaka ryšiams su Lietuva}

Kalbant apie pastaruosius metus, reikia pažymèti, kad Rusijos Baltijos politikai vis didesnę įtaka besikeičiantys Rusijos ryšius su Vakarais. Dešimtojo dešimtmečio pradžioje Vakarų valstybės (ypač JAV) atsižvelgè į kritiškas Maskvos pastabas dèl NATO plètros. Vašingtonas nebuvo pasirengęs aštrinti santykių su Rusija. Tačiau po keleto metu padetis pasikeite - buvo ruošiamasi naujų narių priemimui. Kritiškas Rusijos požiūris apsiribojo žodiniais gąsdinimais, tačiau realiu veiksmų nebuvo imtasi: galima teigti, kad Rusija nebuvo linkusi pyktis, nes valstybę slégè didžiulès skolos Vakarams. Aljansas irgi neskubëjo: kalbėdami apie Baltijos šalių prièmimą, NATO vadovai tikslių datų nenurodè. 1999 metais, pasirašius Baltijos Chartija, prasidëjo derybos dèl naujų narių prièmimo. Baltijos šalims džiugiai prièmus šią žinia, Rusijai darėsi vis sunkiau bendrauti su Vakarais.

Rusijos valdžios vairą perèmus V. Putinui, keitėsi ir Rusijos užsienio politika. Pirmiausia buvo atsisakyta „Primakovo doktrinos“ , pradètas dialogas su JAV ir Europa. Nors ir būdamas Boriso Jelcino „ipèdiniu“, Putinas èmėsi novatoriškų žingsnių. 1999 metais viršūnių susitikime Helsinkyje dėstydamas

\footnotetext{
${ }^{31}$ Karabeshkin L. „Rossija, ES i problema Kaliningrada“, Evropei skaia bezopasnost': sobytiia, otsenki, prognozy, no. 3 (19). Moscow: INION RAS, 2006. p. 7-9.
} 
savo mintis apie ekonomikos ryšius su Europa, jis nurodè, kad Kaliningradas turètų būti pirmasis atviras užsienio bendrovèms regionas. Tiesa, Prezidentas nenurodè, koks tai turètų būti bendradarbiavimas. Viena aišku, kad tai įrodė Rusijos vadovybės siekị palaikyti draugiškus santykius su Europa.

Po tragiškų 2001 metų rugsėjo 11 d. įvykių Maskvos ir Vašingtono dialogas sustiprëjo. Abi šalys suprato turinčios bendrų uždavinių kovoje prieš tarptautini terorizmą. Bendradarbiavimas buvo apvainikuotas 2002 metais ịkūrus Rusijos ir NATO tarybą. Tarybos įkūrimas tarytum buvo moralinė kompensacija Rusijai, nes ji atvirai nesipriešino NATO plètrai ị rytus. Santykiuose su Lietuva irgi pastebėta pozityviu pokyčiu. Manyta, kad būdama NATO nare Lietuva padès Šiaurès Aljanso šalims bendrauti su Rusija. Kalbėdamas JAV Kongreso Atstovų Rūmų Europos pakomitečio posėdyje Lietuvos ambasadorius Jungtinėse Valstijose V. Ušackas pabrèžè, kad Baltijos šalims tapus NATO narèmis Europa taptų stabilesnè, taip pat stiprintu Aljanso ryšius su Rusija ${ }^{32}$.

Jau kitais metais draugiškumas èmè blèsti. Nors atvirai ir nesmerke, Rusija nepritarè prasidejjusiai Amerikos invazijai į Iraką. Rusija sunerimo - keliose NVS šalyse i̇vyko vadinamosios ",spalvotosios" revoliucijos, posovietinëje erdvèje didèjo Vakaru valstybių įtaka. Pati Rusija buvo kaltinama žmogaus teisių pažeidimais uždarius „Jukos“ bendrovę. Atmesdama kaltinimus, Maskva teigè, kad Vakarų siūlomos demokratijos ir žmogaus teisių idëjos netinka ju šaliai. Savo ruožtu Rusijos elitas pasiūlè „suverenios demokratijos“ idèją.

İtampa, atsiradusi tarp Rusijos ir Vakaru, dare įtaką ir santykiams su Baltijos valstybėmis. Tapusios Europos Sajungos ir NATO narėmis, šios šalys pradejjo kritikuoti Rusijos politiką. Prezidentas Adamkus aktyviai rẻmé Ukrainos „oranžinę revoliuciją“, taip pat Lietuva palaikė naujają Gruzijos valdžią. Lietuva nepanoro dalyvauti šešiasdešimtosiose Antrojo pasaulinio karo baigties metinèse Maskvoje $2005 \mathrm{~m}$. gegužès $9 \mathrm{~d}$.. Didelio atgarsio sulaukè ir Rusijos diplomatu, apkaltintų šnipinéjimu, išsiuntimas iš Lietuvos.

Žinoma, Maskva nepritare tokiems kaimynu žingsniams. Rusijai nepatiko, kad Lietuva ėmėsi tarpininko tarp Vakaru valstybių ir NVS šalių vaidmens. Rusija ne tiek bijojo Lietuvos įtakos, kiek vis didejjančios JAV ir Europos Sajungos įtakos tose šalyse. Baltijos šalys buvo pirmosios posovietinès respublikos, priimtos į šias organizacijas. Durys neužsivèrè, tad nors Vašingtonas žada nepažeisti Rusijos interesu, nerimas išlieka.

Ilgai nelaukdama Rusija ėmėsi atsakomujų veiksmų. Pirmiausia stengtasi izoliuoti Baltijos šalis, menkinant ju ìvaizdị. Be to, stengtasi atkreipti pasaulio dèmesį i t tai, kad, atsisakydamos vykti ị iškilmes, jos negerbia Antrojo pasaulinio karo ir nacių auku. Rusija siūlo skirstyti Europą į senają ir naujają̧. İ 750 metų Kaliningrado jubiliejų naujosios ES ir NATO narès - Baltijos šalys ir Lenkija nèra kviečiamos. Jos aplenkiamos ir svarstant svarbius ekonominius projektus. Rusija ir Vokietija pasirašo Šiaurès Europos dujotiekio, kuris aplenks tiek Lietuvos, tiek ir Lenkijos teritorijas, tiesimo sutarti.

\footnotetext{
${ }^{32}$ NATO Enlargement: A View from the Candidate Countries. Hearings before the Subcommittee on Europe, Committee on International Relations. House of Representatives. $107^{\text {th }}$ Congress, Second session, serial no. 107-8, May 1, 2002, p. 43.
} 


\section{Vidinis užsienio politikos kontekstas}

Atkūrusi nepriklausomybę ir norėdama išlaikyti valstybinį vientisumą, Lietuva ėmėsi užsienio priešu paieškos. Juk niekas taip nesuvienija šalies, kaip grèsmè iš svetur. Pagrindinis tikslas buvo atkreipti į save didžiujų demokratiniu valstybių žvilgsnius ir gauti ekonominę paramą. Piktadario vaidmeniui pasirinkta buvusi metropolija. Stiprëjant Lietuvos valstybei, užsienio priešo įvaizdis silpnèjo. Bet net ir dabar jaučiamos neigiamos nuostatos Rusijai.

Evaldo Nekrašo žodžiais tariant, santykiai su Rusija yra lengvai pažeidžiami: įstojus į Europos Sajungą ir NATO, ne tik nesumažejo, bet ir paaštrëjo Rusijos karinè, politinè ir ekonomine grèsmé ${ }^{33}$. Vis dar išlieka nepasitikejjimas šios šalies vykdoma politika. Tai ne tik Lietuvos ir politiku, ir žiniasklaidos minima autoritarinio valdymo grèsmé, bet ir Rusijos vidaus procesų neišmanymas. Užuot ėmusis politinès ir ekonominės analizės, dažnokai pasitelkiami ideologiniai vertinimais. Taigi nors Lietuva ir mano esanti posovietinių šalių žinovė, Rusija jai kartais atrodo nepažįstama.

Lietuvos žmonès vis dar nepasitiki Rusija. Manyčiau, kad tokios visuomenės nuotaikos stiprëja. Dabartinės apklausos rodo, kad 46,2\% Lietuvos gyventojų tiki, jog Rusija kelia grèsmę jų šaliai, priešingai manančių yra 39,1\% ${ }^{34}$. Lietuvoje nepasitikejimas Rusija yra pats didžiausias iš visų buvusių Sovietiniu Respubliku; antroje vietoje šiuo požiūriu yra Latvija, trečioje Gruzija ${ }^{35}$.

Pastaruju metu iivykiai - Prezidento Rolando Pakso apkalta, Viktoro Uspaskicho politinè izoliacija, gaisras "Mažeikių naftoje“ - rodo, kad Lietuva vis dar bijo "Maskvos rankos“, t. y. Rusijos keliamos grèsmès. İdomu, kodèl nebijoma "Vašingtono rankos", nepaisant tos žalos, kurią Lietuva patyrè dèl JAV valdžios remiamos "Williams" kompanijos nuostolingos veiklos. Rusijos bijomasi kaip ideologinio priešo. Informacinès grèsmès, kylančios iš rytų, nuotaikas palaiko ir Lietuvos žiniasklaida - spauda bei televizija.

Lietuvos užsienio politikoje taip pat vyrauja baimė dèl Rusijos veiksmu. Dèl to stengiamasi atsiriboti nuo jos ir stiprinti euroatlantinius ryšius, palaikant glaudžius santykius su Vašingtonu. Vienas iš prioritetu yra pagalba kai kurioms NVS šalims integruotis į Europos Sajungą ir NATO. Šie žingsniai ne tik padeda Jungtinèms Valstijoms ịsitvirtinti posovietinëje erdvëje, bet yra naudingi ir pačiai Lietuvai. Tikima, kad Lietuva negali visiškai pasitikèti senosiomis Europos šalimis. Siekdamos sau naudos, jos gali sudaryti sandorius su Rusija, naująsias nares palikdamos nuošalyje. Padėdama buvusioms NVS šalims, Lietuva igyja naujų sąungininkių.

Viena iš šalių nesutarimo priežasčiu yra skirtingas $X X$ a. istorijos vertinimas. Lietuva ne kartą siūlė dvišalėse derybose svarstyti sovietinę okupaciją. Rusija atsisako tai daryti motyvuodama, kad šalies ịstojimas į Sovietų Sąungą

\footnotetext{
${ }^{33}$ Nekrašas E., „Lithuanian Foreign Policy: Achievements, Concepts and Predicaments“, Lithuanian Foreign Policy Review, no. 1-2. 2004, p. 28-35.

${ }^{34}$ BNS, 2006 spalio mèn. $19 \mathrm{~d}$.

${ }^{35}$ Golov A., ,Strany-druz’ia i strany-vragi dlia Rossii: peremeny za god“, June 5, 2006, http://www.levada. ru/press/2006060502.html.
} 
1940 metais buvo savanoriškas. Pasak Putino, šis istorijos tarpsnis yra sudėtingas ir nereikètu jo politizuoti ${ }^{36}$. Nereikètų manyti, kad abi šalys skirtingai suvokia istoriją. Rusija nenori derètis, nes mano, kad tai nepagerins dvišalių santykių. Atsiprašydama už okupacijos padarytą žalą ji tik suteiktų Lietuvos politiniam elitui galimybę reikalauti piniginės kompensacijos.

\section{Išvados}

Viename iš interviu Lietuvos Respublikos ambasadorius Rusijoje R. Šidlauskas teigè, kad abiejų šaliu bendravimas - tiek teisinis, tiek ir praktinis - vyksta sklandžiai. Visi neatidèliotini reikalai išspręsti - baigtos derybos sienos klausimais, pasirašytos tarpvalstybinès sutartys. Tačiau ambasadorius paminëjo neigiamas psichologines nuostatas ${ }^{37}$ : Lietuvai ir Rusijai trūksta abipusio pasitikèjimo. O tai stabdo ekonominį bendradarbiavimą, vidaus ir užsienio politikos raidą. Tokia padètis nèra naudinga nei Lietuvai, nei Rusijai. Kalbant apie dvišalius santykius nereikètu būti pesimistu. 15 metų laikotarpis įrodè, kad šalys stengiasi atsisakyti neigiamų nuostatu, suprasdamos bendravimo naudą. Šalys turi bendrų uždavinių ūkio raidos, ekologijos srityse.

Ilgalaikès prognozès yra optimistinès. Rusijos santykiai su Jungtinèmis Valstijomis ir Europos Sąunga gerès, šalys stengsis mažiau konkuruoti, skatins bendradarbiavimą ir partnerystę. Keičiantis pasaulio politikai ir Baltijos šalys suvoks, kokie svarbūs yra ryšiai su Rytu kaimynėmis. Sustiprès regioniniai ryšiai - tiek ekonominiai, tiek ir humanitariniai. Lietuva atsisakys išankstiniu neigiamų nuostatų ir pradės politinį dialogą su Rusija.

\footnotetext{
${ }^{36}$ Vladimiro Putino spaudos konferencija Tarptautiniame spaudos centre Strelnoje, Sankt-Peterburge, Vladimir Putin had a press briefing at the International Press Centre in Strelna, St Petersburg. July 17, 2006, http://www.mid.ru/brp_4.nsf/sps/6831F8C1E83F4664C32571AE002A97E6.

${ }^{37} \mathrm{BNS}, 2006$ gegužès mèn. $17 \mathrm{~d}$.
} 